\title{
Combining Thermotherapy with Cryotherapy for Efficient Eradication of Apple stem grooving virus from Infected In-vitro-cultured Apple Shoots
}

Lei Zhao, College of Plant Protection, Northwest A\&F University; Min-Rui Wang, State Key Laboratory of Crop Stress Biology for Arid Areas, College of College of Horticulture, Northwest A\&F University, Yangling 712100, Shaanxi, China; Zhen-Hua Cui and Long Chen, State Key Laboratory of Crop Stress Biology for Arid Areas, College of College of Horticulture, Northwest A\&F University; Gayle M. Volk, United States Department of Agriculture-Agricultural Research Service National Laboratory for Genetic Resources Preservation, Fort Collins, CO 80521; and Qiao-Chun Wang, ${ }^{\dagger}$ State Key Laboratory of Crop Stress Biology for Arid Areas, College of College of Horticulture, Northwest A\&F University

\begin{abstract}
Apple stem grooving virus (ASGV), a difficult-to-eradicate virus from apple propagative materials, causes serious damage to apple production. The use of virus-free plants has been and is an effective strategy for control of plant viral diseases. This study aimed to eradicate ASGV from virus-infected in-vitro-cultured shoots of four apple cultivars and one rootstock by combining thermotherapy with cryotherapy. In vitro stock shoots infected with ASGV were thermo-treated using an alternating temperature of $36^{\circ} \mathrm{C}$ (day) and $32^{\circ} \mathrm{C}$ (night). Shoot tips were excised from the treated stock shoots and subjected to cryotherapy. Results showed that, although thermotherapy did not influence shoot survival rates, it reduced shoot growth and proliferation of in vitro shoots. Shoot regrowth rates decreased while virus eradication frequencies increased in cryo-treated shoot tips as time durations of thermotherapy increased from 0 to 6 weeks. Shoot regrowth and frequency of virus eradication were positively and negatively

correlated, respectively, with the size of shoot tips. The protocol established here yielded shoot regrowth rates and virus eradication frequencies of 33 to $76 \%$ and 30 to $100 \%$, respectively, in the four apple cultivars and one rootstock. Thermotherapy altered virus distribution patterns, subsequently resulting in production of a larger virus-free area in the thermo-treated shoot tips. Many cells in the top layers of apical dome and some cells in the youngest leaf primordia survived in cryo-treated shoot tips; these cells were most likely free of virus infection. Thus, plants regenerated from the procedure of combining thermotherapy with cryotherapy were free of ASGV, as judged by reverse-transcription polymerase chain reaction. To the best of our knowledge, this is the widestspectrum technique reported thus far for the production of ASGV-free plants and provides a novel biotechnology for the production of virusfree plants in Malus spp.
\end{abstract}

Virus diseases have long been a threat to sustainability of apple production (Hadidi and Barba 2011). For a long time, certified virus-tested propagation materials have been used for efficient control of plant virus diseases (Faccioli and Marani 1998; Laimer and Barba 2011; Massart et al. 2011; Mink et al. 1998). Over the past four decades, great efforts have been exerted to develop reliable techniques for the production of apple virus-free propagative materials. Various traditional methods have been developed, including shoot tip culture (STC) (Laimer and Barba 2011; Plopa and Preda 2013), thermotherapy followed by STC (Laimer and Barba 2011; Paprstein et al. 2008; Tan et al. 2010; Wang et al. 2006), micrografting (Conejero et al. 2013; Dobránszki and Da 2010; Huang and Millikan 1980; Laimer and Barba 2011), chemotherapy followed by STC (Hansen and Lane 1985; James et al. 1997; O'Herlihy et al. 2003; Sedlak et al. 2011), and a combination of chemotherapy and thermotherapy (Hu et al. 2012, 2015).

Apple stem grooving virus (ASGV), the type member of the genus Capillovirus, has been reported in many apple-growing regions all over the world (Massart et al. 2011). A recent survey in China showed that ASGV was widely spread in all apple-growing regions and its infection frequency was $73.7 \%$ (Ji et al. 2013). ASGV is one of the most important latent viruses that infect Malus plants and other fruit crops, including Pyrus, Citrus, and Actinidia spp., as well as a

${ }^{\dagger}$ Corresponding author: Q.-C. Wang; E-mail: qiaochunwang@ nwsuaf.edu.cn M.-R. Wang and L. Zhao contributed equally to the present study.

Funding: Financial support was provided by the National Natural Science Foundation of China (number 31701761), the Department of Science and Technology of Shaanxi Province (number 2014KTCL02-05), and the Chinese Universities Scientific Fund (number 2452017061).

Accepted for publication 19 February 2018.

C) 2018 The American Phytopathological Society number of important ornamental crops (Massart et al. 2011). ASGV infection caused graft incompatibility, reduced growth vigor, and decreased fruit yield (Massart et al. 2011). Previous studies showed that ASGV was the most difficult-to-eradicate virus from apple propagative materials among the other apple viruses such as Apple chlorotic leafspot virus (ACLSV), Apple stem pitting virus (ASPV), and Apple mosaic virus (ApMV) (Campbell 1968; Cropley 1968; Knapp et al. 1995; Li et al. 2016; Wang et al. 2006; Wang et al. 2016).

Cryotherapy has proven to be an efficient strategy for the production of virus-free plants (Romadanova et al. 2016; Vieira et al. 2015; Wang and Valkonen 2009; Wang et al. 2008). Romadanova et al. (2016) reported that cryotherapy could eradicate ASGV from invitro-cultured shoots but the virus-free frequency was lower than for other viruses such as ACLSV, ASPV, and ApMV. Li et al. (2016) found cryotherapy resulted in 80 to $85 \%$ frequencies of ASPV-free plantlets in two apple rootstocks (M9 and M26) but completely failed in producing ASGV-free plantlets. Combining thermotherapy with cryotherapy was proven to be more efficient than cryotherapy alone to eradicate Raspberry bushy dwarf virus (RBDV) that is able to infect meristematic tissues from in-vitro-cultured raspberry shoots (Wang et al. 2008).

The objective of this study was to test the efficacy of combining thermotherapy with cryotherapy in eradicating ASGV from in-vitro-cultured apple shoots. Possible mechanisms for successful virus eradication were discussed using data generated from virus localization in the infected shoot tips and histological observations on cell survival patterns in cryo-treated shoot tips.

\section{Materials and Methods}

Plant material. Malus $\times$ domestica 'Gala' apple was used to establish a virus eradication procedure by combining thermotherapy with cryotherapy. Three other apple cultivars (Malus $\times$ domestica 'Fuji', 'Ruixue' and 'Nongguo 25') and a rootstock (Malus paradisiaca 'M9') were further tested for their virus eradication by combining thermotherapy with cryotherapy established in the present study. Gala and Ruixue were used in experiments of histological observations 
and virus localization. In vitro shoots infected with ASGV that had been obtained by STC, as described by Wang et al. (2016), were maintained on shoot maintenance medium (SMM) composed of Murashige and Skoog (1962) medium (MS) supplemented with sucrose at 30 $\mathrm{g} \mathrm{liter}^{-1}, 6$-benzyladenine at $0.25 \mathrm{mg} \mathrm{liter}^{-1}$, indole-3-butyric acid at $0.01 \mathrm{mg} \mathrm{liter}^{-1}$, and agar at $8 \mathrm{~g} \mathrm{liter}^{-1}$, as described by Feng et al. (2013). The $\mathrm{pH}$ of the medium was adjusted to 5.8, prior to autoclaving at $121^{\circ} \mathrm{C}$ for $20 \mathrm{~min}$. The stock cultures were kept at a constant temperature of $24 \pm 2{ }^{\circ} \mathrm{C}$ under a 16-h photoperiod with a light intensity of $50 \mu \mathrm{E} \mathrm{s}^{-1} \mathrm{~m}^{-2}$ provided by cool-white fluorescent tubes. Subculture was performed once every 4 weeks.

Thermotherapy. Shoot segments (1 to $2 \mathrm{~cm}$ long) containing two to three nodes were excised from 4-week-old diseased stock shoots and cultured on SMM in the same light conditions used for maintenance of the in vitro stock cultures. After 2 weeks of culture, the shoot segments were moved into a growth chamber (PQX-400; Haixiang Equipment, Shanghai, China) with the same light conditions as used for the in vitro stock shoots. An alternating temperature was set at $36^{\circ} \mathrm{C}$ (day) and $32^{\circ} \mathrm{C}$ (night). Effects of thermotherapy on survival, growth, and proliferation of in vitro stock shoot were analyzed.

STC and cryotherapy. Two experiments were performed in combining thermotherapy with cryotherapy for virus eradication. In the first experiment, shoot tips (1.5 mm in length) containing 4 to 5 leaf primordia (LP) were excised from in vitro diseased stock shoots after $0,2,4$, and 6 weeks of thermotherapy. These treatments were designated as $\mathrm{Th}_{0 \mathrm{wk}}, \mathrm{Th}_{2 \mathrm{wks}}, \mathrm{Th}_{4 \mathrm{wks}}$, and $\mathrm{Th}_{6 \mathrm{wks}}$, respectively. The excised shoot tips were divided into two groups: one for STC (designated as $\mathrm{Th}+\mathrm{STC}$ ) and another for cryotherapy (designated as Th + Cryo). In $\mathrm{Th}+\mathrm{STC}$, explants were cultured for shoot recovery on SMM in the same light conditions used for maintenance of the in vitro stock cultures. In Th + Cryo, three sizes of shoot tips ( $1.5 \mathrm{~mm}$ in length containing 2 to $3 \mathrm{LP}, 1.5 \mathrm{~mm}$ containing 4 to $5 \mathrm{LP}$, and $2.0 \mathrm{~mm}$ containing 5 to $6 \mathrm{LP})$ were excised from in vitro diseased stock shoots receiving $\mathrm{Th}_{4 \mathrm{wks}}$ and subjected to cryotherapy, as described by $\mathrm{Li}$ et al. (2015). The excised shoot tips were incubated in SMM for 1 day, followed by preculture in liquid MS containing $2 \mathrm{M}$ glycerol and $0.8 \mathrm{M}$ sucrose for 1 day. The precultured shoot tips were exposed to plant vitrification solution 2 (PVS2) (Sakai et al. 1990) at room temperature for $40 \mathrm{~min}$. PVS2 contained 30\% (wt/vol) glycerol, 15\% (wt/vol) ethylene glycol, 15\% (wt/vol) dimethylsulfoxide, and $0.4 \mathrm{M}$ sucrose in MS ( $\mathrm{pH}$ 5.8). After dehydration, each shoot tip was transferred into 2.5- $\mu$ l PVS 2 droplets carried on sterile aluminum foil strips ( 1.8 by $0.4 \mathrm{~cm}$ ) and then directly immersed in liquid nitrogen (LN) for $30 \mathrm{~min}$. Cryo-treated shoot tips were rapidly rewarmed by removing the frozen aluminum foil strips from $\mathrm{LN}$ and immediately placing them in unloading solution containing 1.2 M sucrose in MS at room temperature for $20 \mathrm{~min}$. The cryo-treated shoot tips were postcultured on SMM. The cultures were placed in the dark for 3 days, during which they were transferred to fresh SMM every 16 to $24 \mathrm{~h}$ to reduce browning (Li et al. 2015). After that, the shoot tips were transferred to light conditions for shoot regrowth, which was defined as percentage of the total number of shoot tips regenerating into normal shoots $(\geq 5 \mathrm{~mm})$ 4 weeks postculture.

In Th + STC and Th + Cryo, subculture was conducted once every 4 weeks until shoots ( $\geq 1.5 \mathrm{~cm}$ in length) with three to four fully opened leaves formed in about 3 months. Shoots ( $\geq 1.5 \mathrm{~cm}$ in length) were transferred onto rooting medium (RM) and placed under the light conditions. RM was composed of MS supplemented with sucrose at $30 \mathrm{~g} \mathrm{liter}^{-1}$, naphthalene acetic acid at $0.5 \mathrm{mg} \mathrm{liter}^{-1}$, and agar at $8 \mathrm{~g} \mathrm{liter}^{-1}$ ( $\mathrm{pH}$ 5.8). After 4 weeks of rooting, plantlets with welldeveloped roots were transferred into soil and grown in screenhouse conditions, according to Feng et al. (2013).

Virus detection. The sanitary status of plant materials was tested twice in the present study using reverse-transcription polymerase chain reaction (RT-PCR). ASGV was detected in the in vitro stock shoots to ensure that all plant materials were virus infected before thermotherapy. ASGV was detected again in the regenerated plants to assess virus eradication frequency; these plants had been grown in a screenhouse for 10 months, a period that encompasses one dormant season (from August 2015 to June 2016).

RT-PCR was conducted according to MacKenzie et al. (1997), with some modifications. Total RNA was extracted from fresh tissue
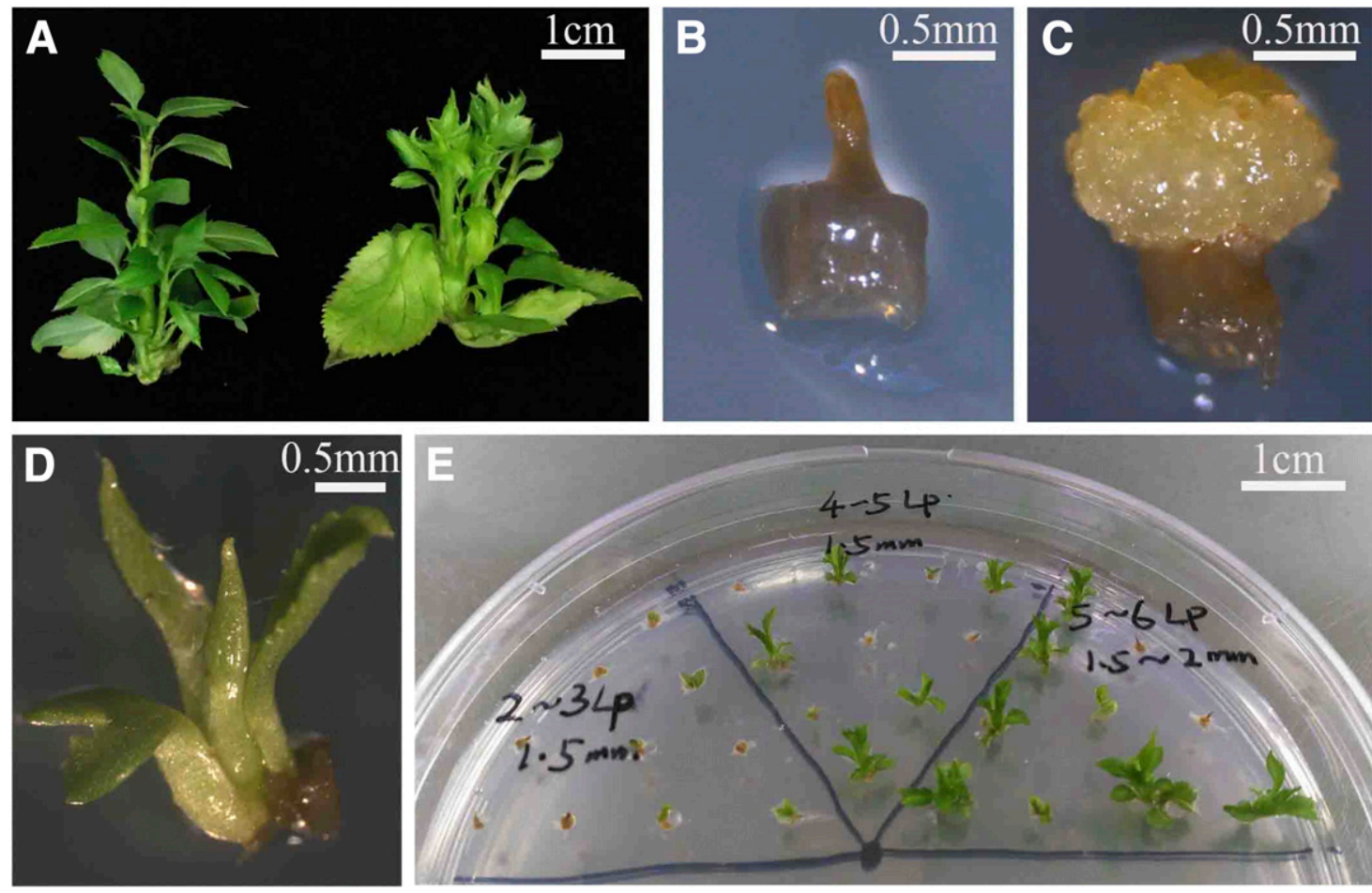

Fig. 1. Apple stem grooving virus (ASGV)-infected shoot of Gala following thermotherapy and shoot regeneration after thermotherapy combined with cryotherapy. A, ASGV-infected in vitro stock cultures without thermotherapy (in the left) and with thermotherapy at an alternating temperature of $36^{\circ} \mathrm{C}$ (day) and $32^{\circ} \mathrm{C}$ (night) for 4 weeks (on the right). B, Dead shoot tip after cryotherapy following thermotherapy. C, Callus formation from surviving shoot tip after cryotherapy following thermotherapy. D, Normal shoot regenerated 4 weeks postculture following thermotherapy and cryotherapy. E, Recovery of three sizes of shoot tips, as indicated on the Petri dish, following thermotherapy and cryotherapy after 4 weeks of postthaw culture. LP = leaf primordia. 
(0.5 g) using Trizol Reagent (Invitrogen Ltd., Carlsbad, CA), according to the manufacturer's instructions. cDNA was synthesized on $2 \mu \mathrm{g}$ of total RNA using recombinant Moloney murine leukemia virus reverse transcription (Promega Corp., Madison, WI), according to the manufacturer's instructions. The forward primer (5'-CTGCAAGACCGCGACCAAGTTT-3') and reverse primer (5'-CCCGCTGTTGGATTTGATACACCTC-3') were used to amplify a product of $524 \mathrm{bp}$ (MacKenzie et al. 1997). The PCR was performed in a $25-\mu \mathrm{l}$ reaction volume containing $1 \mu \mathrm{l}$ of $0.5 \mu \mathrm{M}$ each primer, $12.5 \mu \mathrm{l}$ of $2 \times$ Taq DNA polymerase Mix (Kangwei, Beijing, China), $2 \mu$ l of template cDNA, and $8.5 \mu l$ of RNAase-free water. The PCR products were separated by electrophoresis in $2 \%$ agarose gels in Tris-acetate-EDTA buffer $(40 \mathrm{mM}$ Tris-acetate and $1 \mathrm{mM}$ EDTA, $\mathrm{pH}$ 8.0), stained with ethidium bromide, and visualized under an ultraviolet light.

Histological observations. The highest and lowest frequencies of virus-free plants were obtained in Gala and Ruixue following Th + Cryo. Therefore, these two cultivars were used for histological observations and virus localization, as described below, to elucidate a mechanism for efficient eradication of ASGV and understand why virus-free frequencies vary with host genotypes in the procedure combining thermotherapy with cryotherapy. Shoot tips were collected 3 days postculture following cryotherapy and $\mathrm{Th}_{4 \mathrm{wks}}+$ Cryo, and processed according to Feng et al. (2013). In brief, samples were fixed in $50 \%$ ethanol/formalin/acetic acid (18:1:1), dehydrated, and embedded. Thin sections $(5 \mu \mathrm{m})$ were cut with a microtome (Leica RM 2235; Nussloch, Germany) and stained with $0.1 \%$ toluidine blue (TB) (Sakai 1973). The stained sections were observed under a light microscope (Leica DM 2000). Shoot tips without any treatments were used as positive controls to show characteristics of living cells, while those that were freshly excised, directly immersed in LN, and postcultured for 3 days served as negative controls to show characteristics of dead cells. Both positive and negative controls underwent the same histological processes as described above.

Table 1. Effects of thermotherapy on survival, regrowth, and proliferation of Apple stem grooving virus (ASGV)-infected in-vitro-cultured shoots of Gala apple $^{\mathrm{z}}$

\begin{tabular}{lcccc}
\hline Treatment & $\begin{array}{c}\text { Survival } \\
(\%)\end{array}$ & $\begin{array}{c}\text { Mean } \\
\text { length of } \\
\text { shoots }(\mathbf{c m})\end{array}$ & $\begin{array}{c}\text { Number of } \\
\text { proliferated } \\
\text { shoots/explant }\end{array}$ & $\begin{array}{c}\text { Leaf } \\
\text { color }\end{array}$ \\
\hline Thermotherapy & $100 \mathrm{a}$ & $2.5 \pm 0.3 \mathrm{~b}$ & $4.7 \pm 0.9 \mathrm{a}$ & Yellowish \\
$\begin{array}{l}\text { Nonthermotherapy } \\
\text { (control) }\end{array}$ & $100 \mathrm{a}$ & $3.5 \pm 0.4 \mathrm{a}$ & $2.5 \pm 0.6 \mathrm{~b}$ & Green \\
\hline
\end{tabular}

${ }^{\mathrm{z}} \mathrm{ASGV}$-infected in-vitro-cultured shoots were thermo-treated at an alternating temperature of $36^{\circ} \mathrm{C}$ (day) and $32^{\circ} \mathrm{C}$ (night) for 4 weeks. Data were presented as means \pm standard error; different letters in the same parameter indicate significant differences at $P<0.05$ by Student's $t$ test.

Table 2. Shoot regrowth and Apple stem grooving virus (ASGV) eradication frequency by combining thermotherapy with shoot tip culture (STC) or cryotherapy (Cryo) in Gala applew

\begin{tabular}{lccccc}
\hline & \multicolumn{2}{c}{ Shoot regrowth $(\%)^{\mathbf{x}}$} & & \multicolumn{2}{c}{$\begin{array}{c}\text { Frequency of ASGV } \\
\text { eradication }(\%)^{\mathbf{y}}\end{array}$} \\
\cline { 2 - 3 } \cline { 6 - 6 } Time (weeks) & STC & Cryo & & STC & Cryo \\
\hline 0 & $100.0 \mathrm{a}$ & $62.2 \pm 3.2 \mathrm{a}$ & & $0(0 / 15)$ & $0(0 / 15)$ \\
2 & $88.9 \pm 6.3 \mathrm{ab}$ & $55.5 \pm 3.2 \mathrm{ab}$ & & $0(0 / 15)$ & $20(3 / 15)$ \\
4 & $77.8 \pm 3.2 \mathrm{~b}$ & $44.4 \pm 6.3 \mathrm{~b}$ & & $20.0(3 / 15)$ & $93(14 / 15)$ \\
6 & $64.5 \pm 3.2 \mathrm{c}$ & $20.0 \pm 5.5 \mathrm{c}$ & & $40.0(6 / 15)$ & $100(12 / 12)$ \\
\hline
\end{tabular}

${ }^{\mathrm{w}}$ ASGV-infected stock shoots were treated at an alternating temperature of $36^{\circ} \mathrm{C}$ (day) and $32^{\circ} \mathrm{C}$ (night) for 4 weeks. Shoot tips $(1.5 \mathrm{~mm})$ containing 4 to 5 leaf primordia were used for STC and Cryo.

$x$ Data of shoot regrowth rates are presented as means \pm standard error; different letters in the same column indicate significant differences at $P<0.05$ by Student's $t$ test.

y Numbers in parentheses are plantlets negative reaction to ASGV/total samples analyzed by reverse-transcription polymerase chain reaction.

$z$ Duration of thermotherapy.
Virus localization. Shoot tips were taken from virus-infected in vitro stock shoots of Gala and Ruixue after treatments of $\mathrm{Th}_{0 \mathrm{wk}}$, $\mathrm{Th}_{2 \mathrm{wks}}$, and $\mathrm{Th}_{4 \mathrm{wks}}$ and prepared for virus localization, as described by $\mathrm{Li}$ et al. (2016). The healthy in vitro shoots were used as negative controls. Briefly, the thin sections $(5 \mu \mathrm{m})$, as produced for histological observations, were treated with phosphate-buffered saline (PBS) containing $4 \%$ bovine serum albumin for $30 \mathrm{~min}$, followed by overnight incubation at $5^{\circ} \mathrm{C}$ with the polyclonal antibodies (dilution 1: 400 in PBS) (150812; Bioreba, Reinach, Switzerland) to ASGV coat protein. After washing in PBS three times, the samples were incubated with antirabbit antibodies conjugated with alkaline phosphatase (A3937; Sigma-Aldrich, St. Louis) (dilution 1:400 in PBS) for $30 \mathrm{~min}$ at room temperature. After rinsing three times with PBS, samples were stained using a freshly prepared Fuchsin substrate solution. The sections were observed using a light microscope (Leica DM 750).

Experimental design and data statistical analysis. Ten samples were included in each treatment of three replicates in experiments of $\mathrm{Th}+\mathrm{STC}$ and $\mathrm{Th}+\mathrm{Cryo}$, and all experiments were conducted twice. The data were presented as means \pm standard error and analyzed using one-directional analysis of variance. Least significant differences were calculated at $P<0.05$ by Student's $t$ test. Ten samples were used in each treatment of two replicates in virus localization and histological observations. In all, 15 plants recovered from $\mathrm{Th}+\mathrm{STC}$ and $\mathrm{Th}+$ Cryo were used for virus detection, except in the treatment of $\mathrm{Th}_{6 \mathrm{wks}}+$ Cryo, where only 12 regenerated plants were available.

\section{Results}

Effect of thermotherapy on survival, growth, and proliferation. After $\mathrm{Th}_{4 \mathrm{wk}}$, all in vitro shoots of Gala survived. Leaves of heat-treated

Table 3. Shoot tip size on shoot regrowth and Apple stem grooving virus (ASGV) eradication of Gala after combining thermotherapy with cryotherapy $^{\mathrm{w}}$

\begin{tabular}{lcc}
\hline Size of shoot tips & Shoot regrowth $(\%)^{\mathbf{y}}$ & $\begin{array}{c}\text { Frequency of ASGV } \\
\text { eradication }(\boldsymbol{\%})^{\mathbf{z}}\end{array}$ \\
\hline $1.5 \mathrm{~mm}+2$ to 3 LP & $11.1 \pm 3.1 \mathrm{~b}$ & $100(15 / 15)$ \\
$1.5 \mathrm{~mm}+4$ to 5 LP & $46.7 \pm 5.4 \mathrm{a}$ & $100(15 / 15)$ \\
$2.0 \mathrm{~mm}+5$ to 6 LP & $49.5 \pm 4.1 \mathrm{a}$ & $73(11 / 15)$ \\
\hline
\end{tabular}

${ }^{\mathrm{w}} \mathrm{ASGV}$-infected stock shoots were thermo-treated at an alternating temperature at $36^{\circ} \mathrm{C}$ (day) and $32^{\circ} \mathrm{C}$ (night) for 4 weeks, followed by cryotherapy.

${ }^{x} \mathrm{LP}=$ leaf primordia.

y Data of shoot regrowth rates are presented as means \pm standard error; different letters indicate significant differences at $P<0.05$ by Student's $t$ test.

z Numbers in parentheses are plantlets negative reactions to ASGV/total samples analyzed by reverse-transcription polymerase chain reaction.

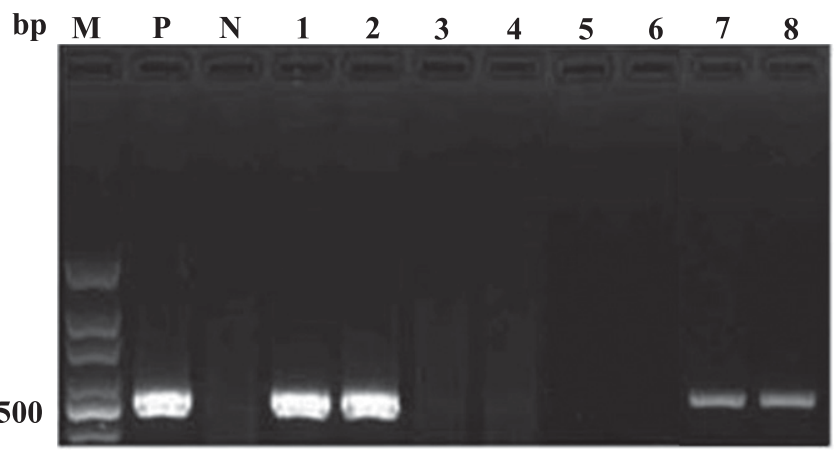

Fig. 2. Detection of Apple stem grooving virus (ASGV) by reverse-transcription polymerase chain reaction in Gala apple. Lane $M=$ molecular marker, lane $P=$ positive control (ASGV-infected Gala apple), lane $\mathrm{N}=$ negative control (virus-free Gala apple), lanes 1 and 2 = ASGV-infected in-vitro-cultured stock shoots before thermotherapy, lanes 3 and $4=$ plants regenerated from the procedure combining thermotherapy for 4 weeks with cryotherapy, lanes 5 and $6=$ plants regenerated from the procedure combining thermotherapy for 4 weeks with shoot tip culture, lane 7 = plants regenerated from the procedure combining thermotherapy for 2 weeks with cryotherapy, and lane $8=$ plants regenerated from the procedure combining thermotherapy for 4 weeks with shoot tip culture. 
shoots turned yellowish, particularly those at base of the shoots, compared with the nonthermo-treated control (Fig. 1A; Table 1). Although numbers of proliferating shoots per explant (4.7) were greater in thermo-treated shoots than those of the control (2.5), the latter

Table 4. Shoot regrowth and Apple stem grooving virus (ASGV) eradication by combining thermotherapy with shoot tip culture (STC) or cryotherapy (Cryo) in three apple cultivars and one apple rootstock ${ }^{\mathrm{y}}$

\begin{tabular}{lccccc}
\hline & \multicolumn{2}{c}{$\begin{array}{c}\text { Shoot } \\
\text { regrowth }(\%)\end{array}$} & & \multicolumn{2}{c}{$\begin{array}{c}\text { Frequency of ASGV } \\
\text { eradication }(\%)^{\mathbf{z}}\end{array}$} \\
\cline { 2 - 3 } \cline { 5 - 6 } Genotypes & STC & Cryo & & STC & Cryo \\
\hline M9 (rootstock) & 76 & 38 & & $36(4 / 11)$ & $83(5 / 6)$ \\
Fuji (cultivar) & 63 & 33 & & $38(5 / 13)$ & $100(5 / 5)$ \\
Ruixue (cultivar) & 90 & 76 & & $7(1 / 14)$ & $30(4 / 13)$ \\
Nongguo 25 (cultivar) & 83 & 66 & & $8(1 / 12)$ & $40(2 / 5)$ \\
\hline
\end{tabular}

${ }^{y}$ An alternating temperature of $36^{\circ} \mathrm{C}$ (day) $32^{\circ} \mathrm{C}$ (night) was used to treat the virus-infected stock shoots for 4 weeks. Shoot tips $(1.5 \mathrm{~mm})$ containing 4 to 5 leaf primordia were excised from the heat-treated stock shoots and used for STC and Cryo.

${ }^{\mathrm{z}}$ Numbers in parentheses are plantlets negative reaction to ASGV/total samples analyzed by reverse-transcription polymerase chain reaction. produced much longer shoots $(3.5 \mathrm{~cm})$ than the former $(2.5 \mathrm{~cm})$ (Fig. 1A; Table 1).

Effects of Th + STC and Th + Cryo on shoot regrowth and virus eradication. Shoot regrowth rates in $\mathrm{Th}+\mathrm{STC}$ and $\mathrm{Th}+\mathrm{Cryo}$ significantly decreased as time durations of thermotherapy increased from 0 to 6 weeks (Table 2). STC and $\mathrm{Th}_{2 \mathrm{wks}}+\mathrm{STC}$ were not able to produce any ASGV-free plants (Table 2). Frequencies of ASGV eradication were 20 and $41 \%$ in shoot tips excised from in vitro shoots receiving treatments of $\mathrm{Th}_{4 \mathrm{wks}}$ and $\mathrm{Th}_{6 \mathrm{wks}}$, respectively. Following $\mathrm{Th}+\mathrm{Cryo}$, three types of shoot tips formed. Dead shoot tips turned brown and black (Fig. 1B). About $10 \%$ of surviving shoot tips produced only callus, without shoot regeneration (Fig. 1C). Normal shoots directly regenerated without callus formation within 8 weeks postculture (Fig. 1D). Cryotherapy without thermotherapy did not produce any ASGV-free plants (Table 2). Frequencies of ASGV-free plants produced by $\mathrm{Th}+$ Cryo significantly increased from 20 to $100 \%$ as time durations of thermotherapy increased from 2 to 6 weeks (Table 2). In Th + Cryo, size of shoot tips affected shoot regrowth rate and virus eradication frequency (Fig. 1E; Table 3). Shoot regrowth rates increased as size of shoot tips increased from $1.5 \mathrm{~mm}$ containing 2 to $3 \mathrm{LP}$ to $1.5 \mathrm{~mm}$ containing 4 to $5 \mathrm{LP}$ and 1.5 to $2.0 \mathrm{~mm}$ containing 5 to 6 LP. However, virus eradication frequencies decreased with
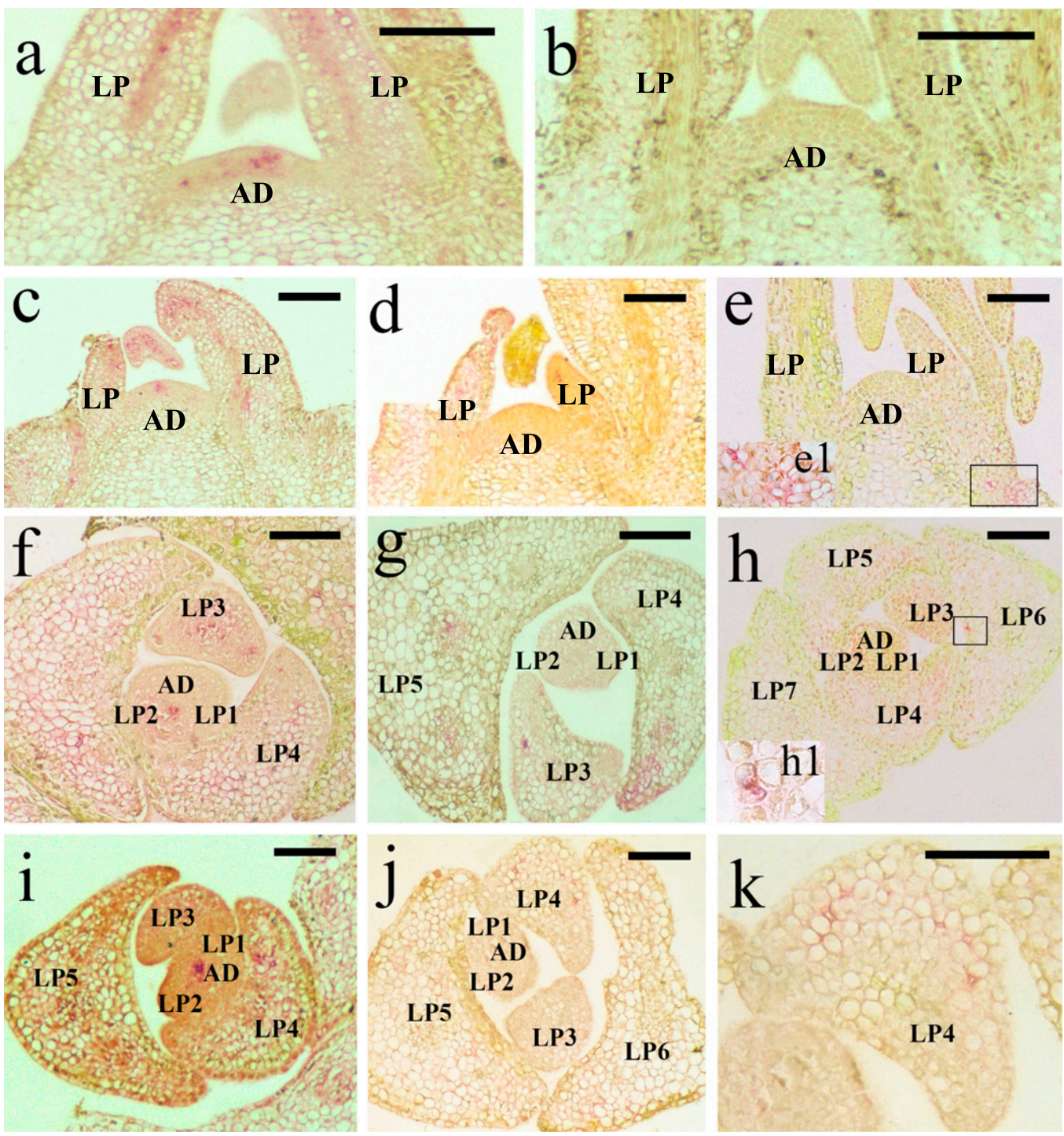

Fig. 3. Immunolocalization of Apple stem grooving virus (ASGV) in the virus-infected apple shoot tips of Gala and Ruixue after thermotherapy at an alternating temperature of $36^{\circ} \mathrm{C}$ (day) and $32^{\circ} \mathrm{C}$ (night). Virus-infected cells show a color reaction, while healthy cells do not. Longitudinal sections of a, ASGV-infected (positive control) and $\mathbf{b}$, healthy (negative control) Gala shoot tips. Longitudinal sections of Gala shoot tips after c, 0 ; d, 2; and e, 4 weeks of thermotherapy. e1, A closer view showing virus-infected cells in the black square in e. Cross sections of Gala shoot tips after $\mathbf{f}, \mathbf{0 ;} \mathbf{g}, 2$; and $\mathbf{h}, 4$ weeks of thermotherapy. $\mathbf{h} 1$, A closer view showing virus-infected cells in the black square in $\mathrm{h}$. Cross sections of Ruixue shoot tips after i, 0 and j, 4 weeks of thermotherapy. $\mathbf{k}$, A closer view of the leaf primordium 4 (LP4) in j. AD = apical dome. Bars $=100 \mu \mathrm{m}$. 
increases in size of shoots from $1.5 \mathrm{~mm}$ containing 2 to 3 and 4 to $5 \mathrm{LP}$ to 1.5 to $2.0 \mathrm{~mm}$ containing 5 to $6 \mathrm{LP}$ (Table 3 ).

Virus detection. An ASGV-specific band of 524 bp produced by RT-PCR was detected in all diseased in vitro stock shoots that were used for virus eradication but was absent in the virus-free negative control Gala apple (Fig. 2). When RT-PCR was applied on plants recovered from $\mathrm{Th}+\mathrm{STC}$ or Th + Cryo, samples showing such specific bands were considered to be ASGV infected, while those without such specific bands were considered to be ASGV free (Fig. 2).

Applications of Th + STC and Th + Cryo to other apple genotypes. Shoot regrowth rates and virus eradication frequencies varied with apple genotypes (Table 4). With Th + STC, the lowest $(63 \%)$ and highest $(90 \%)$ shoot regrowth rates were found in Fuji and Ruixue, and the lowest (7\%) and highest (38\%) virus eradication frequencies were produced in Ruixue and Fuji (Table 4). With Th + Cryo, shoot regrowth rates were the lowest (33\%) in Fuji and the highest $(76 \%)$ in Ruixue, and virus eradication frequencies were the lowest $(30 \%)$ in Ruixue and the highest (100\%) in Fuji (Table 4).

ASGV localization. A purple color reaction formed in the ASGVinfected cells of the positive control (Fig. 3a), whereas no such color reaction was found in the healthy cells (Fig. 3b). In diseased Gala stock shoots, strong purple color reactions were easily seen in the very top cells in the apical dome (AD) and the youngest LP in shoot tips before thermotherapy (Fig. $3 \mathrm{c}$ and $\mathrm{f}$ ). After $\mathrm{Th}_{2 \mathrm{wks}}$, virus was not found in the AD and LP1 but was still found in LP3 and older LP (Fig. 3d). Virus was also detected in LP2 in 6 of 12 samples tested, accounting for $40 \%$ (Fig. $3 \mathrm{~d}$ and g). After $\mathrm{Th}_{4 \mathrm{wks}}$, virus was not detected in the AD and LP1 to -5 but was still detected in LP6 and older LP (Fig. 3e, h). In Ruixue stock shoots, a similar pattern of virus distribution was found in the diseased shoot tips before thermotherapy (Fig. 3i). After $\mathrm{Th}_{4 \mathrm{wks}}$, virus was not detected in the AD and LP1 to -3 but was found in LP5 and older LP (Fig. 3j). Virus was also detected in LP4 in 16 of 20 samples tested, accounting for $80 \%$ (Fig. 3j and $\mathrm{k}$ ).

Histological observations. In the positive control, living cells showed TB-stained dense color with fully integrated cytoplasm and nucleolus enclosed in the nucleus (Fig. 4a and a1). In the negative control, dead cells did not show TB-stained cytoplasm, and cell membranes were ruptured and the nuclei were heavily condensed (Fig. 4b and b1). In Gala, the majority of the cells in the AD and some cells in LP1 to -4 survived in shoot tips following cryotherapy without thermotherapy (Fig. 4c, c1, and c2). Following $\mathrm{Th}_{4 \mathrm{wks}}+$ Cryo, many cells located in the top layers of the AD and some cells in LP1 to -3 survived, whereas other cells were killed in shoot tips (Fig. 4d,
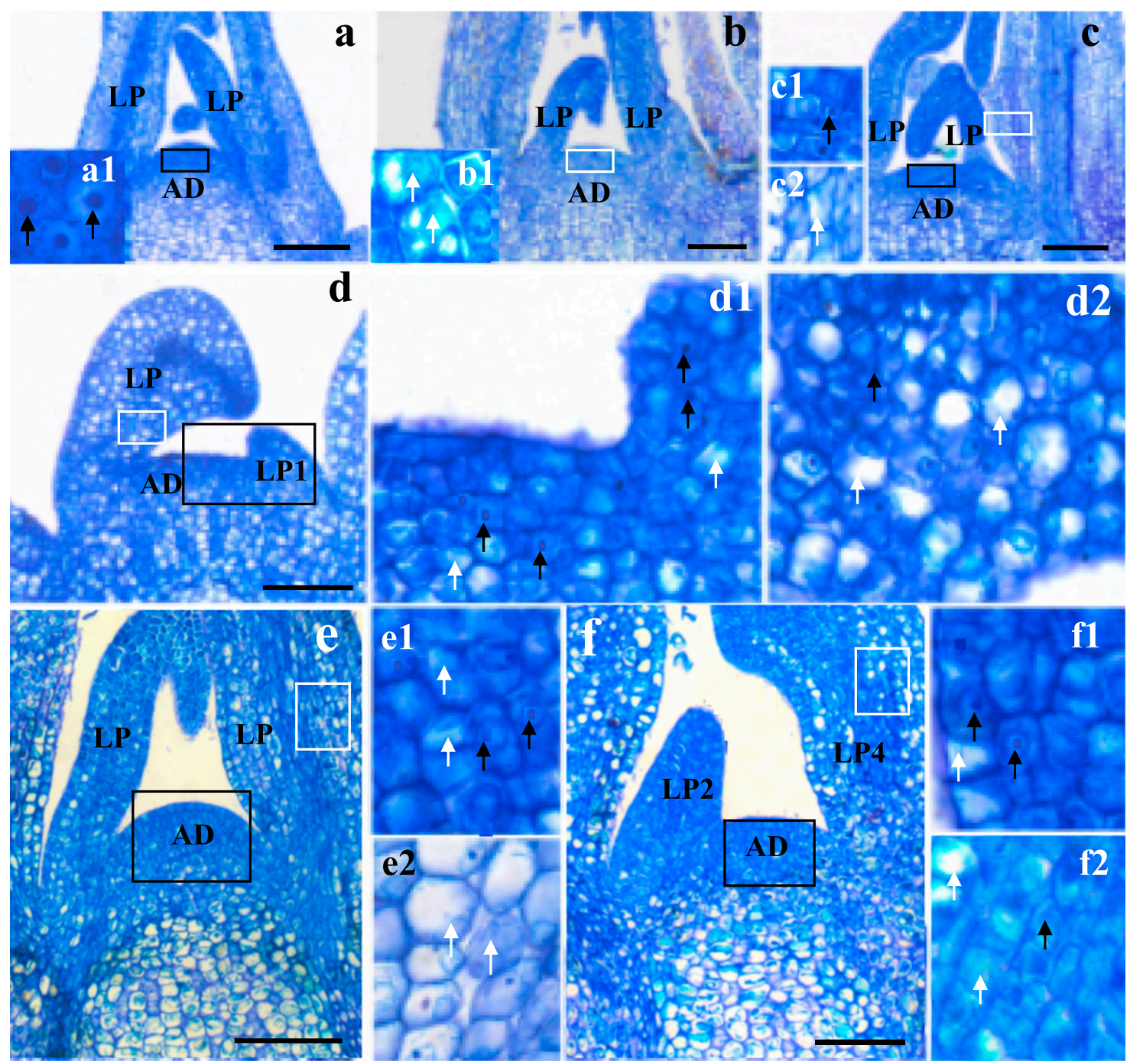

Fig. 4. Histological observations of cell survival patterns in cryo-treated shoot tips with and without thermotherapy in Gala and Ruixue apple. a, A Gala shoot tip that was freshly excised from 4-week-old stock shoots, serving as a positive control. a1, A closer view showing typical surviving cells in the black square of apical dome (AD) in a. b, A Gala shoot tip that was excised from 4-week-old stock culture and immediately immersed in liquid nitrogen for $1 \mathrm{~h}$, serving as a negative control. b1, A closer view showing damaged or dead cells in the white square of $A D$ in b. c, A Gala shoot tip following cryotherapy without thermotherapy. Closer views of $c 1, A D$ and c2, leaf primordium (LP) 5 in c. d, A Gala cryo-treated shoot tip following 4 weeks of thermotherapy. Closer views of the d1, black square of $A D$ and d2, white square of $L P$ in $d$. e, A Ruixue cryo-treated shoot tip following 4 weeks of thermotherapy. Closer views of the $\mathrm{e} 1$, black square of $\mathrm{AD}$ and $\mathrm{e2}$, white square of $\mathrm{LP}$ in $\mathrm{e} . \mathrm{f}, \mathrm{A}$ Ruixue cryo-treated shoot tip following 4 weeks of thermotherapy. Closer views of the f1, black square of $A D$ and f2, white square of $L P$ in f. Black and white arrows represent surviving and damaged cells, respectively. Bars $=100 \mu \mathrm{m}$. 
$\mathrm{d} 1$, and d2). In Ruixue, cell survival patterns in cryo-treated shoot tips without thermotherapy were similar to those of Gala (Fig. 4e, e1, and e2). However, many cells located in the top layers of the AD and in LP1 to -3 survived, and some cells in LP4 were also found alive in shoot tips following $\mathrm{Th}_{4 \mathrm{wks}}+$ Cryo (Fig. 4f, f1, and f2).

\section{Discussion}

STC and Th + STC are among the traditional approaches that have been the most frequently used for virus eradication in Malus propagative materials (Campbell 1968; Cropley 1968; Faccioli and Marani 1998; Knapp et al. 1995; Li et al. 2016; Mink et al. 1998; Paprstein et al. 2008; Wang et al. 2016). In STC, the size of shoot tips is critical for shoot regrowth and virus eradication (Faccioli and Marani 1998; Li et al. 2016; Mink et al. 1998; Wang et al. 2016). Working on apple rootstocks M9 and M26, Li et al. (2016) found that shoot recovery rates were much higher in $0.5-$ or $1.0-\mathrm{mm}$ shoot tips containing 3 or $4 \mathrm{LP}$ than in $0.5-\mathrm{mm}$ shoot tips containing $2 \mathrm{LP}$. However, ASPVfree frequencies significantly decreased as size of shoot tips increased from 0.5 to $1.0 \mathrm{~mm}$ and LP number increased from 2 to 3 or 4 . Similar results were also obtained in apple rootstocks M9 and M26 (Li et al. 2016) and cultivar Gala (Wang et al. 2016). The studies of Li et al. (2016) and Wang et al. (2016) further found that STC completely failed to eradicate ASGV from infected in-vitro-cultured apple shoots, regardless of the size of the shoot tips. These results and ours support the idea that ASGV is a virus that is difficult to eradicate from apple propagative materials.

Thermotherapy temperatures affected shoot survival, growth, and proliferation of the thermo-treated in-vitro-cultured stock shoots, as well as survival and shoot regeneration of shoot tips excised from the thermo-treated in vitro shoots (Hu et al. 2012, 2015; Knapp et al. 1995; Paprstein et al. 2008; Tan et al. 2010). Although constant or alternating temperatures can be applied to the stock cultures, the latter can alleviate negative effects of high constant temperature on the stock cultures and STC. For example, Knapp et al. (1995) reported that all in vitro apple shoots survived after they were thermotreated by an alternating temperature of $38^{\circ} \mathrm{C}$ (day) and $36^{\circ} \mathrm{C}$ (night) for 33 days. Beneficial effects of alternating temperature treatments on survival, growth, and proliferation were also reported by Tan et al. (2010) in pear and in the present study.

The extent of virus eradication was affected by the duration and temperature of the thermotherapy, as well as the size of the in vitro shoots. Thermotherapy of apple plants at $36^{\circ} \mathrm{C}$ for 20 days followed by the excision of 1-mm shoot tips produced higher frequencies of plants free of ACLSV (80 to 85\%), ASPV (74 to 80\%), and ASGV (70 to $86 \%$ ) than when plants were treated at $34^{\circ} \mathrm{C}$ ( $\mathrm{Hu}$ et al. 2015). Tan et al. (2010) found that thermotherapy of pear plants at $37^{\circ} \mathrm{C}$ for 35 days followed by culture of $1.0-\mathrm{mm}$ shoot tips produced ASGV- and ACLSV-free pear plants, and that no virus-free plants were obtained in shoot tips larger than $2.0 \mathrm{~mm}$. They also found that diseased in-vitro-cultured shoots that had been heat treated for more than 55 days with an alternating temperature of $42^{\circ} \mathrm{C}$ (day) and $34^{\circ} \mathrm{C}$ (night), followed by the excision of $1.0-\mathrm{mm}$ shoot tips, resulted in $100 \%$ of the regenerated plants free of ACLSV, ASPV, and ASGV. The results obtained in the present study were consistent with those reported by Tan et al. (2010), Paprstein et al. (2008), and Hu et al. (2015).

Romadanova et al. (2016) reported that ASGV could be eradicated by cryotherapy alone. However, results from our previous study ( $\mathrm{Li}$ et al. 2016) and the present study showed that cryotherapy alone completely failed to eradicate ASGV. In the studies of Li et al. (2016) and Wang et al. (2016) and this study, virus localization in shoot tips without thermotherapy clearly showed that meristematic cells were heavily infected by ASGV, while these cells survived following cryotherapy. Therefore, plants regenerated from cryo-treated shoot tips were still ASGV infected. Nevertheless, virus-host combinations and cryotherapy methods used in the study of Romadanova et al. (2016), and those of Li et al. (2016) and this study might be responsible for the differences in ASGV eradication. In addition, virus was detected in the plants regenerated only after 6 to 8 weeks following cryotherapy in the study of Romadanova et al. (2016), during which the virus numbers might be too low to be detected.
In the current ASGV study, we found that regrowth levels of cryotreated shoot tips decreased and the frequency of virus eradication increased as the length of thermotherapy increased from 0 to 4 to 6 weeks. We also found that size of excised shoot tips after thermotherapy affected shoot regrowth and virus eradication. Similar results were also reported by Wang et al. (2008) for the eradication of RBDV from infected in vitro raspberry shoots. There are only a limited number of studies that have assessed the distribution of viruses in thermo-treated shoot tips. Wang et al. (2010) observed ACLSV and ASGV in 1-mm shoot tips without thermotherapy in diseased pear in vitro shoots. After a 50-day thermotherapy treatment, ACLSV and ASGV were not detected in shoot tips smaller than 2.0 and $0.5 \mathrm{~mm}$, respectively. The virus-free area was enlarged in raspberry in vitro shoot tips infected with RBDV after thermotherapy for 28 days (Wang et al. 2008). In the present study, we found that the virus-free areas after thermotherapy varied among apple cultivars. Following $\mathrm{Th}_{4 \mathrm{wks}}$, ASGV was not detected in the AD and LP1 to -5 in Gala but it was detected in LP4 in Ruixue. Following Th + Cryo, surviving cells were observed in the AD and LP1 to -4 in both Gala and Ruixue. These differences explained why there was a much higher frequency of ASGV eradication in Gala than in Ruixue, as well as why virus-free frequencies varied among other apple genotypes tested in the present study. Due to a limited number of plants available in other apple genotypes tested, statistical analysis was not done in virus-free frequencies among them in the present study.

High-temperature treatment was found to inhibit viral replication (Cooper and Walkey 1978), prevent virus movement toward the meristematic cells (Mink et al. 1998), cause virus RNA degradation (Wang et al. 2008), or induce gene silencing (Chellappan et al. 2005). More recently, Liu et al. $(2015,2016)$ found that thermotherapy $\left(37^{\circ} \mathrm{C}\right)$ caused upregulation of the expression of several key genes involved in RNA silencing, induced the biogenesis of versus iRNA, and inhibited viral RNA accumulation in pear in vitro shoot tips infected with ASGV. These alternations may eventually contribute to production of larger virus-free areas in the heat-treated shoot tips than in nontreated ones (Wang et al. 2008; Wang et al. 2010).

In conclusion, a protocol combining thermotherapy with cryotherapy for efficient production of ASGV-free plants was developed in the present study. To the best of our knowledge, this is the most wide-spectrum technique thus far reported for ASGV eradication and provides a novel biotechnology for production of apple plants free of ASGV, the most difficult-to-eradicate virus in Malus spp.

\section{Literature Cited}

Campbell, A. 1968. Heat Sensitivity of Some Apple Viruses. Tagungsber. Dal DDR, Berlin. 97:311-316

Chellappan, P., Vanitharani, R., Ogbe, F., and Fauquet, C. M. 2005. Effect of temperature on geminivirus-induced RNA silencing in plants. Plant Physiol 138:1828-1841.

Conejero, A., Romero, C., Cunill, M., Mestre, M. A., Martínez-Calvo, J., Badenes, M. L., and Llácer, G. 2013. In vitro shoot-tip grafting for safe Prunus budwood exchange. Sci. Hortic. (Amsterdam) 150:365-370.

Cooper, V. C., and Walkey, D. 1978. Thermal inactivation of Cherry leaf roll virus in tissue cultures of Nicotiana rustica raised from seeds and meristem-tips. Ann. Appl. Biol. 88:273-278.

Cropley, R. 1968. Comparison of some apple latent viruses. Ann. Appl. Biol. 61: 361-372.

Dobránszki, J., and Da, S. J. 2010. Micropropagation of apple-a review. Biotechnol. Adv. 28:462-488.

Faccioli, G., and Marani, F. 1998. Virus elimination by meristem tip culture and tip micrografting. Pages 346-380 in: Plant Virus Disease Control. A. Hadidi, R. H. Khetarpal, and H. Koganezawa, eds. American Phytopathological Society, St. Paul, MN.

Feng, C. H., Cui, Z. H., Li, B. Q., Chen, L., Ma, Y. L., Zhao, Y. H., and Wang, Q. C. 2013. Duration of sucrose preculture is critical for shoot regrowth of in vitrogrown apple shoot-tips cryopreserved by encapsulation-dehydration. Plant Cell Tissue Organ Cult. 112:369-378.

Hadidi, A., and Barba, M. 2011. Economic impact of pome and stone fruit viruses and viroids. Pages 1-7 in: Virus and Virus-Like Diseases of Pome and Stone Fruits. A. Hadidi, M. Barba, T. Candresse, and W. Jelkmann, eds. American Phytopathological Society, St. Paul, MN.

Hansen, A., and Lane, W. 1985. Elimination of apple chlorotic leafspot virus from apple shoot cultures by ribavirin. Plant Dis. 69:134-135. 
Hu, G., Dong, Y., Zhang, Z., Fan, X., Ren, F., and Zhou, J. 2015. Virus elimination from in vitro apple by thermotherapy combined with chemotherapy. Plant Cell Tissue Organ Cult. 121:435-443.

Hu, G., Hong, N., Wang, L., Hu, H., and Wang, G. 2012. Efficacy of virus elimination from in vitro-cultured sand pear (Pyrus pyrifolia) by chemotherapy combined with thermotherapy. Crop Prot. 37:20-25.

Huang, S. C., and Millikan, D. F. 1980. In vitro micrografting of apple shoot tips. HortScience 15:741-743.

James, D., Trytten, P., Mackenzie, D., Towers, G., and French, C. 1997. Elimination of Apple stem grooving virus by chemotherapy and development of an immunocapture RT-PCR for rapid sensitive screening. Ann. Appl. Biol. 131: 459-470.

Ji, Z., Zhao, X., Duan, H., Hu, T., Wang, S., Wang, Y., and Cao, K. 2013. Multiplex RT-PCR detection and distribution of four apple viruses in China. Acta Virol. 57:435-441.

Knapp, E., Hanzer, V., Weiss, H., Câmara, M., Weiss, B., Wang, Q., Katinger, H., and Laimer, M. 1995. New aspects of virus elimination in fruit trees. Acta Hortic. 386:409-418.

Laimer, M., and Barba, M. 2011. Elimination of systemic pathogens by thermotherapy, tissue culture, or in vitro micrografting. Pages 389-393 in: Virus and Virus-Like Diseases of Pome and Stone Fruits. A. Hadidi, M. Barba, T. Candresse, and W. Jelkmann, eds. American Phytopathological Society, St. Paul, MN.

Li, B. Q., Feng, C. H., Hu, L. Y., Wang, M. R., and Wang, Q. C. 2016. Shoot tip culture and cryopreservation for eradication of Apple stem pitting virus (ASPV) and Apple stem grooving virus (ASGV) from apple rootstocks 'M9' and 'M26'. Ann. Appl. Biol. 168:142-150.

Li, B. Q., Feng, C. H., Wang, M. R., Hu, L. Y., Volk, G., and Wang, Q. C. 2015. Recovery patterns, histological observations and genetic integrity in Malus shoot tips cryopreserved using droplet-vitrification and encapsulation-dehydration procedures. J. Biotechnol. 214:182-191.

Liu, J., Zhang, X., Yang, Y., Hong, N., Wang, G., Wang, A., and Wang, L. 2016. Characterization of virus-derived small interfering RNAs in Apple stem grooving virus-infected in vitro-cultured Pyrus pyrifolia shoot tips in response to high temperature treatment. Virol. J. 13:166.

Liu, J., Zhang, X., Zhang, F., Hong, N., Wang, G., Wang, A., and Wang, L. 2015. Identification and characterization of microRNAs from in vitro-grown pear shoots infected with Apple stem grooving virus in response to high temperature using small RNA sequencing. BMC Genomics 16:945.

MacKenzie, D. J., McLean, M. A., Mukerji, S., and Green, M. 1997. Improved RNA extraction from woody plants for the detection of viral pathogens by reverse transcription-polymerase chain reaction. Plant Dis. 81:222-226.

Massart, S., Jijakli, M. H., and Kummert, J. 2011. Apple stem grooving virus. Pages 29-33 in: Virus and Virus-Like Diseases of Pome and Stone Fruits. A. Hadidi, M. Barba, T. Candresse, and W. Jelkmann, eds. American Phytopathological Society, St. Paul, MN.
Mink, G., Wample, R., and Howell, W. 1998. Heat treatment of perennial plants to eliminate phytoplasmas, viruses and viroids while maintaining plant survival. Pages 332-345 in: Plant Virus Disease Control. A. Hadidi, R. H. Khetarpal, and H. Koganezawa, eds. American Phytopathological Society, St. Paul, MN.

Murashige, T., and Skoog, F. 1962. A revised medium for rapid growth and bio assays with tobacco tissue cultures. Physiol. Plant. 15:473-497.

O’Herlihy, E. A., Croke, J. T., and Cassells, A. C. 2003. Influence of in vitro factors on titre and elimination of model fruit tree viruses. Plant Cell Tissue Organ Cult. 72:33-42

Paprstein, F., Sedlak, J., Polak, J., Svobodova, L., Hassan, M., and Bryxiova, M. 2008. Results of in vitro thermotherapy of apple cultivars. Plant Cell Tissue Organ Cult. 94:347-352.

Plopa, C., and Preda, S. 2013. Elimination of Apple mosaic virus by tissue culture of some infected apple cultivars. Acta Hortic. 981:517-522.

Romadanova, N. V., Mishustina, S. A., Gritsenko, D. A., Omasheva, M. Y., Galiakparov, N. N., Reed, B. M., and Kushnarenko, S. V. 2016. Cryotherapy as a method for reducing the virus infection of apples (Malus sp.). Cryo Lett. 37:1-9.

Sakai, A., Kobayashi, S., and Oiyama, I. 1990. Cryopreservation of nucellar cells of navel orange (Citrus sinensis Osb. var. brasiliensis Tanaka) by vitrification. Plant Cell Rep. 9:30-33.

Sakai, W. S. 1973. Simple method for differential staining of paraffin embedded plant material using toluidine blue O. Stain Technol. 48:247-249.

Sedlak, J., Paprstein, F., and Talacko, L. 2011. Elimination of Apple stem pitting virus from pear cultivars by in vitro chemotherapy. Acta Hortic. 923:111-115.

Tan, R. R., Wang, L. P., Hong, N., and Wang, G. P. 2010. Enhanced efficiency of virus eradication following thermotherapy of shoot-tip cultures of pear. Plant Cell Tissue Organ Cult. 101:229-235.

Vieira, R. L., da Silva, A. L., Zaffari, G. R., Steinmacher, D. A., de Freitas Fraga, H. P., and Guerra, M. P. 2015. Efficient elimination of virus complex from garlic (Allium sativum L.) by cryotherapy of shoot tips. Acta Physiol. Plant. 37:1733.

Wang, L., Hong, N., Wang, G., Xu, W., Michelutti, R., and Wang, A. 2010. Distribution of Apple stem grooving virus and Apple chlorotic leaf spot virus in infected in vitro pear shoots. Crop Prot. 29:1447-1451.

Wang, L., Wang, G., Hong, N., Tang, R., Deng, X., and Zhang, H. 2006. Effect of thermotherapy on elimination of Apple stem grooving virus and Apple chlorotic leaf spot virus for in vitro-cultured pear shoot tips. HortScience 41:729-732.

Wang, M. R., Li, B. Q., Feng, C. H., and Wang, Q. C. 2016. Culture of shoot tips from adventitious shoots can eradicate Apple stem pitting virus but fails in Apple stem grooving virus. Plant Cell Tissue Organ Cult. 125:283-291.

Wang, Q. C., Cuellar, W. J., Rajamäki, M.-L., Hirata, Y., and Valkonen, J. P. T. 2008. Combined thermotherapy and cryotherapy for efficient virus eradication Relation of virus distribution, subcellular changes, cell survival and viral RNA degradation in shoot tips. Mol. Plant Pathol. 9:237-250.

Wang, Q. C., and Valkonen, J. P. T. 2009. Cryotherapy of shoot tips: novel pathogen eradication method. Trends Plant Sci. 14:119-122. 